\title{
APLIKASI SISTEM PENDUKUNG KEPUTUSAN PENEMPATAN BIDAN DI DESA MENGGUNAKAN METODE ANALITYCAL HIERARCHY PROCESS (AHP)
}

\author{
Haditsah Annur \\ haditsah@gmail.com \\ Universitas Ichsan Gorontalo
}

\begin{abstract}
Abstrak
Penempatan bidan desa merupakan peningkatan mutu dan pemerataan pelayanan dalam menurunkan angka kematian ibu, anak balita dan menurunkan angka kelahiran serta meningkatkan kesadaran masyarakat untuk berperilaku hidup sehat. Bidan desa mempunyai tugas dan wewenang seperti mempercepat penurunan angka kematian ibu dan anak, meningkatkan cakupan dan pemerataan jangkauan pelayanan kesehatan ibu hamil, pertolongan persalinan dan konseling. Pada penelitian ini akan dibangun media dengan pendekatan sistem pendukung keputusan, dengan menggunakan metode Analytical Hierarchy Process (AHP) dengan bantuan Tools seperti PHP sebagai bahasa pemrogramannya dan MySQL sebagai database. Alasan menggunakan metode ini dibandingkan dengan metode lain karena proses penentuan penempatan bidan desa merupakan permasalahan yang melibatkan banyak komponen atau kriteria yang dinilai (multikriteria). AHP digunakan untuk dapat meningkatkan proses serta kualitas hasil pengambilan keputusan dengan memadukan data dan pengetahuan dalam meningkatkan efektivitas dalam proses pengambilan keputusan.
\end{abstract}

Kata Kunci : Bidan Desa, Sistem Pendukung Keputusan, Analitycal Hierarchy Process (AHP)

\section{Pendahuluan}

Pemerintah daerah melalui Dinas Kesehatan berupaya mewujudkan kebutuhan pelayanan kesehatan dasar di desa, sehingga bidan yang ditempatkan di desa diharapkan dapat berperan secara maksimal dalam menangani masalah kesehatan, khususnya pelayanan kesehatan ibu dan anak. Tujuan penempatan bidan desa yaitu meningkatkan mutu dan pemerataan pelayanan dalam menurunkan angka kematian ibu, anak balita dan menurunkan angka kelahiran serta meningkatkan kesadaran masyarakat untuk berperilaku hidup sehat [1]. Permasalahan yang sering muncul dalam penempatan Bidan Desa adalah tidak meratanya penempatan bidan di setiap desa yang jadi bahan rujukan penempatan. Disisi lain, ada daerah yang kekuatan ekonomi yang kuat, namun ada daerah yang sangat terbelakang, maka situasi ini menyebabkan terjadinya maldistribusi bidan, dan pada daerah tertentu terjadi penumpukan dan pada daerah lainnya terjadi kekurangan bidan (PerMenKes No.7 Thn.2013). Maka dari itu dibutuhkan suatu sistem yang terkomputerisasi agar dapat mengatasi masalah tersebut dan mampu meringankan tugas dari Dinas Kesehatan Provinsi Gorontalo.

Berdasarkan PerMenkes No. 7 Tahun 2013, kententuan umum yang diterapkan dalam penempatan bidan desa seperti :

1. Bidan yang lulus dari pendidikan bidan yang telah teregistrasi sesuai peraturan perundangundangan.

2. Bidan yang bukan pegawai negeri

3. Daerah tertinggal yang relatif kurang berkembang dibandingkan daerah lain dalam skala nasional

4. Daerah kepulauan yang berpenduduk kecil termasuk pulau-pulau kecil terluar.

5. Daerah bermasalah kesehatan (DBK).

Adapun kriteria yang digunakan dalam penempatan bidan disetiap desa maupun daerah kepulauan yaitu : Jarak digunakan untuk mengetahui jangkauan wilayah yang ditempuh dari desa tempat tinggal bidan ke lokasi kerja, yaitu penempatan di desa biasa $(1-3 \mathrm{~km})$, terpencil $(5-8 \mathrm{~km})$ atau sangat terpencil $(9->10 \mathrm{~km}$ ), dapat ditugaskan selama 3 (tiga) tahun, dapat diangkat kembali atau Memperpanjang masa kerjaBidan sebagai PTT paling banyak 2 (dua) kali masa penugasan. Parameter masa kerja bidan (0 bulan - >1 tahun) (PerMenkes No. 7 Tahun 2013).

Seiring dengan kemajuan dunia teknologi informasi yang meliputi perkembangan perangkat keras dan perangkatlunak, ternyata membawa dampak yang multikompleks. Salah satu diantaranya adalah munculnya model pengambilan keputusan yang dikenal dengan Sistem Pendukung Keputusan (SPK) dan menggunakan metode Analitycal Hierarchy Process (AHP)[2]. dimana metode ini dapat memecah suatu masalah yang kompleks dan tidak terstruktur ke dalam bagian-bagiannya. Selain itu 
juga AHP dapat menyajikan hubungan antara faktor, atribut, karakteristik atau alternatif dalam lingkungan pengambilan keputusan. Dengan SPK para pengambil keputusan dalam menentukan kebijakan dapat dilakukan dengan cara yang cepat, efisien dan efektif [3].

Adapun tujuan peneltian ini adalah untuk mengetahui cara merekayasa SPK Penempatan Bidan di Desa Menggunakan metode AHP pada Kantor Dinas Kesehatan Provinsi Gorontalo. Kemudian untuk mengetahui SPK Penempatan Bidan di Desa Menggunakan Metode AHP dapat diimplementasikan.

\section{Metode}

Fuzzy Multiple Attribute Decision Making (FMADM) adalah suatu metode yang digunakan untuk mencari alternatif optimal dari sejumlah alternatif dengan kriteria tertentu. Pada dasarnya, proses FMADM dilakukan melalui 3 tahap, yaitu penyusunan komponen-komponen situasi, analisis, dan sintesis informasi [4]. Pada tahap penyusunan komponen situasi, akan dibentuk tabel taksiran yang berisi identifikasi alternatif dan spesifikasi tujuan, kriteria dan atribut.

\subsection{Analytical Hierarchy Process (AHP)}

AHP merupakan suatu pendekatan praktis untuk memecahkan masalah keputusan kompleks yang meliputi perbandingan alternatif. AHP juga memungkinkan pengambilan keputusan yang menyajikan hubungan hierarki antara faktor, atribut, karakteristik atau alternatif dalam lingkungan pengambilan keputusan [5]. AHP merupakan suatu proses mengidentifikasi, mengerti dan memberikan perkiraan interaksi sistem secara keseluruhan. Prosedur dalam menggunakan metode AHP terdiri dari beberapa tahap yaitu :

1. Menyusun hierarki dari permasalahan yang dihadapi Penyusunan hierarki yaitu dengan menentukan tujuan yang merupakan sasaran sistem secara keseluruhan pada level teratas. Level berikutnya terdiri dari kriteria-kriteria untuk menilai atau mempertimbangkan alternatif-alternatif yang ada dan menentukan alternatif alternatif tersebut. Setiap kriteria dapat memiliki subkriteria dibawahnya dan setiap kriteria dapat memiliki nilai intensitas masing-masing.

2. Menentukan prioritas elemen dengan langkah langkah sebagai berikut:

a. Membuat perbandingan berpasangan Langkah pertama dalam menentukan prioritas elemen adalah membuat perbandingan berpasangan, yaitu membandingkan elemen secara berpasangan sesuai kriteria yang di berikan. Untuk perbandingan berpasangan digunakan bentuk matriks. Matriks bersifat sederhana, berkedudukan kuat yang menawarkan kerangka untuk memeriksakonsistensi, memperoleh informasi tambahan dengan membuat semua perbandingan yang mungkin dan menganalisis kepekaan prioritas secara keseluruhan untuk merubah pertimbangan [5]. Untuk memulai proses perbandingan berpasangan, dimulai dari level paling atas hirarki untuk memilih kriteria, misalnya $C$, kemudian dari level dibawahnya diambil elemen-elemen yang akan dibandingkan, misal $\mathrm{A} 1, \mathrm{~A} 2, \mathrm{~A} 3, \mathrm{~A} 4, \mathrm{~A} 5$, maka susunan elemen pada sebuah matriks seperti Tabel 1 di bawah ini :

Tabel 1. Matrix perbandingan berpasangan

\begin{tabular}{|l|l|l|l|l|l|}
\hline C & A1 & A2 & A3 & A4 & A5 \\
\hline A1 & 1 & & & & \\
\hline A2 & & 1 & & & \\
\hline A3 & & & 1 & & \\
\hline A4 & & & & 1 & \\
\hline A5 & & & & & 1 \\
\hline
\end{tabular}

b. Mengisi matriks perbandingan berpasangan Untuk mengisi matriks perbandingan berpasangan yaitu dengan menggunakan bilangan untuk merepresentasikan kepentingan relatif dari satu elemen terhadap elemen lainnya yang dimaksud dalam bentuk skala dari 1 sampai dengan 9 . Skala ini mendefinisikan dan menjelaskan nilai 1 sampai 9 untuk pertimbangan dalam perbandingan berpasangan elemen pada setiap level hirarki terhadap suatu kreteria di level yang lebih tinggi.Apabila suatu elemen dalam matriks dan dibandingkan dengan dirinya sendiri, maka diberi nilai 1. Jika i dibanding j mendapatkan nilai tertentu, maka j dibanding i merupakan kebalikkannya. Pada tabel 2 memberikan definisi dan penjelasan skala kuantitatif 1 sampai dengan 9 untuk menilai tingkat kepentingan suatu elemen dengan elemen lainnya.

c. Sintesis

Pertimbangan-pertimbangan terhadap perbandingan berpasangan di sintesis untuk memperoleh keseluruhan prioritas dengan langkah-langkah sebagai berikut:

- Menjumlahkan nilai-nilai dari setiap kolom pada matriks. 
- Membagi setiap nilai dari kolom dengan total kolom yang bersangkutan untuk memperoleh normalisasi matriks.

- Menjumlahkan nilai-nilai dari setiap kolom pada matriks dan membaginya dengan jumlah elemen untuk mendapatkan nilai rata-rata.

- Mengukur konsistensi Dalam pembuat keputusan, penting untuk mengetahui seberapa baik konsistensi yang ada, karena kita tidak ingin keputusan berdasarkan pertimbangan dengan konsistensi yang rendah. Karena dengan konsistensi yang rendah, pertimbangan akan tampak sebagai sesuatu yang acak dan tidak akurat. Konsistensi penting untuk mendapatkan hasil yang valid dalam dunia nyata.

AHP mengukur konsistensi pertimbangan dengan rasio konsistensi (consistency ratio). Nilai Konsistensi rasio harus kurang dari 5\% untuk matriks 3x3, 9\% untuk matriks $4 \times 4$ dan 10\% untuk matriks yang lebih besar.

Langkah-langkah menghitung nilai rasio konsistensi yaitu:

a. Mengalikan nilai pada kolom pertama dengan prioritas relatif elemen pertama, nilai pada kolom kedua dengan prioritas relatif elemen kedua, dan seterusnya.

b. Menjumlahkan setiap baris.

c. Hasil dari penjumlahan baris dibagikan dengan elemen prioritas relatif yang bersangkutan.

d. Membagi hasil di atas dengan banyak elemen yang ada, hasilnya disebut eigen value ( $\lambda$ max).

e. Menghitung indeks konsistensi (consistency index) dengan rumus :

Dimana : $\mathrm{Cl}$ : Consistensi Index

$$
\mathrm{Cl}=(\lambda \max -\mathrm{n}) / \mathrm{n}
$$

$\lambda \max$ : Eigen Value

$\mathrm{n} \quad$ : Banyak elemen

f. Menghitung konsistensi ratio (CR) dengan rumus:

Dimana : CR : Consistency Ratio

$$
\mathrm{CR}=\mathrm{Cl} / \mathrm{RC}
$$

\section{$\mathrm{Cl}$ : Consistency Index}

RC : Random Consistency

Matriks random dengan skala penilaian 1 sampai 9 beserta kebalikkannya sebagai random consistency (RC). Berdasarkan perhitungan saaty dengan menggunakan 500 sampel, jika pertimbangan memilih secara acak dari skala $1 / 9,1 / 8, \ldots, 1,2, \ldots, 9$ akan diperoleh ratarata konsistensi untuk matriks yang berbeda.

\section{Hasil dan Pembahasan}

\subsection{Hasil Pengujian AHP}

Perhitungan nilai rasio konsistensi $(C R<=0.1)$ jika ternyata nilai $C R$ lebih besar dari 0.1 maka matriks berpasangan harus diperbaiki. Berikut adalah hasil perhitungan lengkap :

a. Matriks Perbandingan Berpasangan

Tabel 2. Matriks Perbandingan Berpasangan

\begin{tabular}{|c|c|c|c|c|c|c|c|c|}
\hline Kriteria & A1 & A2 & A3 & A4 & A5 & A6 & A7 & A8 \\
\hline A1 & 1,00 & 3,00 & 4,00 & 5,00 & 6,00 & 7,00 & 8,00 & 9,00 \\
\hline A2 & 0,33 & 1,00 & 3,00 & 2,00 & 4,00 & 5,00 & 6,00 & 2,00 \\
\hline A3 & 0,25 & 0,33 & 1,00 & 4,00 & 7,00 & 2,00 & 7,00 & 4,00 \\
\hline A4 & 0,20 & 0,50 & 0,25 & 1,00 & 3,00 & 4,00 & 3,00 & 4,00 \\
\hline A5 & 0,17 & 0,25 & 0,14 & 0,33 & 1,00 & 2,00 & 3,00 & 5,00 \\
\hline A6 & 0,14 & 0,20 & 0,50 & 0,25 & 0,50 & 1,00 & 5,00 & 7,00 \\
\hline A7 & 0,13 & 0,17 & 0,14 & 0,33 & 0,33 & 0,20 & 1,00 & 6,00 \\
\hline A8 & 0,11 & 0,50 & 0,25 & 0,25 & 0,20 & 0,14 & 0,17 & 1,00 \\
\hline Jumlah & $\mathbf{2 , 3 3}$ & $\mathbf{5 , 9 5}$ & $\mathbf{9 , 2 9}$ & $\mathbf{1 3 , 1 7}$ & $\mathbf{2 2 , 0 3}$ & $\mathbf{2 1 , 3 4}$ & $\mathbf{3 3 , 1 7}$ & $\mathbf{3 8 , 0 0}$ \\
\hline
\end{tabular}


ILKOM Jurnal Ilmiah Volume 10 Nomor 1 April 2018

b. Matriks Nilai Kriteria

Tabel 3. Matriks Nilai Kriteria

\begin{tabular}{|c|c|c|c|c|c|c|c|c|r|r|}
\hline Kriteria & A1 & A2 & A3 & A4 & A5 & A6 & A7 & A8 & $\begin{array}{c}\text { Jumlah } \\
\text { Baris }\end{array}$ & $\begin{array}{c}\text { Jumlah } \\
\text { Prioritas }\end{array}$ \\
\hline A1 & 0,43 & 0,50 & 0,43 & 0,38 & 0,27 & 0,33 & 0,24 & 0,24 & 2,82 & 0,35 \\
\hline A2 & 0,14 & 0,17 & 0,32 & 0,15 & 0,18 & 0,23 & 0,18 & 0,05 & 1,44 & 0,18 \\
\hline A3 & 0,11 & 0,06 & 0,11 & 0,30 & 0,32 & 0,09 & 0,21 & 0,11 & 1,30 & 0,16 \\
\hline A4 & 0,09 & 0,08 & 0,03 & 0,08 & 0,14 & 0,19 & 0,09 & 0,11 & 0,79 & 0,10 \\
\hline A5 & 0,07 & 0,04 & 0,02 & 0,03 & 0,05 & 0,09 & 0,09 & 0,13 & 0,52 & 0,06 \\
\hline A6 & 0,06 & 0,03 & 0,05 & 0,02 & 0,02 & 0,05 & 0,15 & 0,18 & 0,57 & 0,07 \\
\hline A7 & 0,05 & 0,03 & 0,02 & 0,03 & 0,02 & 0,01 & 0,03 & 0,16 & 0,33 & 0,04 \\
\hline A8 & 0,05 & 0,08 & 0,03 & 0,02 & 0,01 & 0,01 & 0,01 & 0,03 & 0,22 & 0,03 \\
\hline
\end{tabular}

c. Matriks Penjumlahan Setiap Baris

Tabel 4. Matriks Penjumlahan Setiap Baris

\begin{tabular}{|c|c|c|c|c|c|c|c|c|r|}
\hline Kriteria & A1 & A2 & A3 & A4 & A5 & A6 & A7 & A8 & $\begin{array}{c}\text { Jumlah } \\
\text { Baris }\end{array}$ \\
\hline A1 & 0,35 & 1,06 & 1,41 & 1,76 & 2,12 & 2,47 & 2,82 & 3,18 & 15,17 \\
\hline A2 & 0,06 & 0,18 & 0,54 & 0,36 & 0,72 & 0,90 & 1,08 & 0,36 & 4,19 \\
\hline A3 & 0,04 & 0,05 & 0,16 & 0,65 & 1,14 & 0,33 & 1,14 & 0,65 & 4,17 \\
\hline A4 & 0,02 & 0,05 & 0,02 & 0,10 & 0,30 & 0,40 & 0,30 & 0,40 & 1,58 \\
\hline A5 & 0,01 & 0,02 & 0,01 & 0,02 & 0,06 & 0,13 & 0,19 & 0,32 & 0,77 \\
\hline A6 & 0,01 & 0,01 & 0,04 & 0,02 & 0,04 & 0,07 & 0,36 & 0,50 & 1,04 \\
\hline A7 & 0,01 & 0,01 & 0,01 & 0,01 & 0,01 & 0,01 & 0,04 & 0,25 & 0,35 \\
\hline A8 & 0,00 & 0,01 & 0,01 & 0,01 & 0,01 & 0,00 & 0,00 & 0,03 & 0,07 \\
\hline
\end{tabular}

d. Perhitungan Rasio Konsistensi

Tabel 5. Perhitungan Rasio Konsistensi

\begin{tabular}{|c|c|c|c|}
\hline Kriteria & Jumlah /Baris & Prioritas & Hasil \\
\hline $\mathrm{A} 1$ & 15,17 & 0,35 & 15,52 \\
\hline $\mathrm{A} 2$ & 4,19 & 0,18 & 4,37 \\
\hline A3 & 4,17 & 0,16 & 4,33 \\
\hline A4 & 1,58 & 0,10 & 1,68 \\
\hline A5 & 0,77 & 0,06 & 0,83 \\
\hline A6 & 1,04 & 0,07 & 1,12 \\
\hline A7 & 0,35 & 0,04 & 0,39 \\
\hline A8 & 0,07 & 0,03 & 0,10 \\
\hline \multicolumn{3}{|l|}{ Jumlah } & 28,33 \\
\hline \multicolumn{3}{|l|}{ Jumlah Kriteria } & 8 \\
\hline \multicolumn{3}{|l|}{$\operatorname{Max}(J u m l a h / n)$} & 3,54 \\
\hline \multicolumn{3}{|l|}{ IR } & 1,42 \\
\hline \multicolumn{3}{|l|}{$\mathrm{Cl}($ Max-n)/n } & $-0,56$ \\
\hline \multicolumn{3}{|l|}{$\mathrm{CR}$} & $-0,39$ \\
\hline \multicolumn{3}{|l|}{ Keterangan } & Konsisten \\
\hline
\end{tabular}


ILKOM Jurnal Ilmiah Volume 10 Nomor 1 April 2018

\subsection{Hasil Pengujian SPK}

Tabel 6. Matriks Hasil

\begin{tabular}{|c|c|c|c|c|c|c|c|}
\hline A1 & A2 & A3 & A4 & A5 & A6 & A7 & A8 \\
\hline 0,52 & 4,37 & 4,33 & 1,66 & 0,83 & 1,12 & 0,39 & 0,1 \\
\hline $\begin{array}{c}\text { Sangat } \\
\text { Baik }\end{array}$ & $\begin{array}{c}\text { Sangat } \\
\text { Baik }\end{array}$ & $\begin{array}{c}\text { Sangat } \\
\text { Baik }\end{array}$ & $\begin{array}{c}\text { Sangat } \\
\text { Baik }\end{array}$ & $\begin{array}{c}\text { Sangat } \\
\text { Baik }\end{array}$ & $\begin{array}{c}\text { Sangat } \\
\text { Baik }\end{array}$ & $\begin{array}{c}\text { Sangat } \\
\text { Baik }\end{array}$ & $\begin{array}{c}\text { Sangat } \\
\text { Baik }\end{array}$ \\
\hline 1 & 1 & 1 & 1 & 1 & 1 & 1 & 1 \\
\hline Baik & Baik & Baik & Baik & Baik & Baik & Baik & Baik \\
\hline 0,5 & 0,5 & 0,5 & 0,5 & 0,5 & 0,5 & 0,5 & 0,5 \\
\hline Cukup & Cukup & Cukup & Cukup & Cukup & Cukup & Cukup & Cukup \\
\hline 0,36 & 0,35 & 0,45 & 0,34 & 0,25 & 0,34 & 0,34 & 0,24 \\
\hline Kurang & Kurang & Kurang & Kurang & Kurang & Kurang & Kurang & Kurang \\
\hline 0,25 & 0,15 & 0,12 & 0,12 & 0,14 & 0,23 & 0,12 & 0,1 \\
\hline
\end{tabular}

Tabel 7. Hasil Penilaian

\begin{tabular}{|c|c|c|c|c|c|c|c|c|}
\hline Penilaian & A1 & A2 & A3 & A4 & A5 & A6 & A7 & A8 \\
\hline Herawati Hasan & Baik & $\begin{array}{c}\text { Sangat } \\
\text { Baik }\end{array}$ & Baik & Baik & Baik & Kurang & Kurang & Baik \\
\hline Wita Ngabito & Cukup & Kurang & Cukup & Cukup & Kurang & Baik & Baik & Sangat Baik \\
\hline
\end{tabular}

Tabel 8. Hasil Penilaian

\begin{tabular}{|c|c|c|c|c|c|c|c|c|c|c|}
\hline Penilaian & A1 & A2 & A3 & A4 & A5 & A6 & A7 & A8 & Total & Keterangan \\
\hline Herawati Hasan & 0,26 & 4,37 & 2,165 & 0,83 & 0,415 & 0,2576 & 0,0468 & 0,05 & 8,3944 & Layak \\
\hline Wita Ngabito & 0,1872 & 0,6555 & 1,9485 & 0,5644 & 0,1162 & 0,56 & 0,195 & 0,1 & 4,3268 & Layak \\
\hline
\end{tabular}

\subsection{Pembahasan}

3.3.1 Halaman Beranda

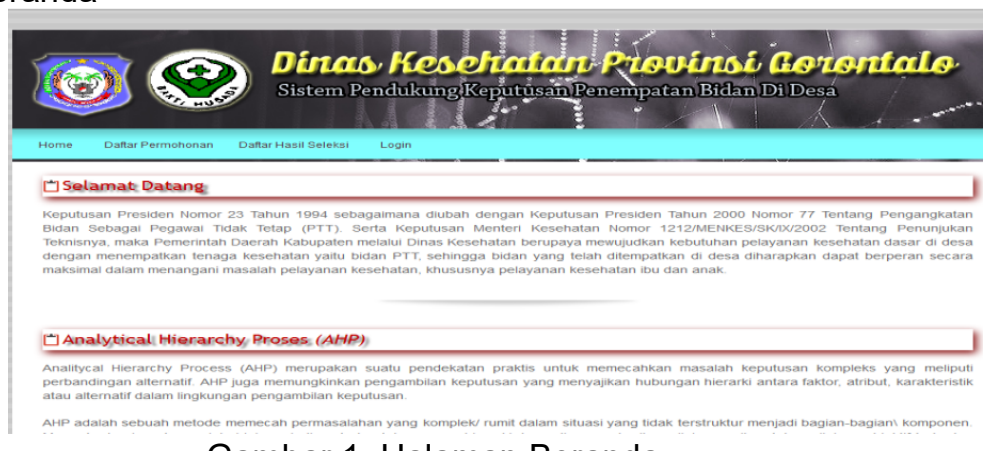

Gambar 1. Halaman Beranda

Form ini digunakan untuk halaman Beranda administrator dan user, untuk menampilkan menu halaman Beranda.

3.3.2 Halaman Menu Login

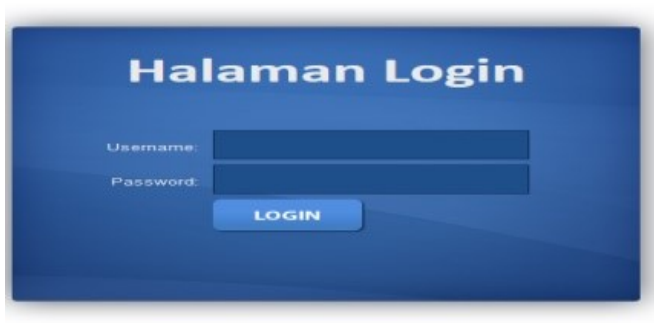

Gambar 2. Halaman Menu Login 
. Halaman Login berfungsi untuk administrator aga dapat mengakses seluruh data, dengan cara Klik tombol login , dengan cara masukkan username dan password untuk menampilkan menu utama 3.2.3 Halaman Menu Utama Administrator

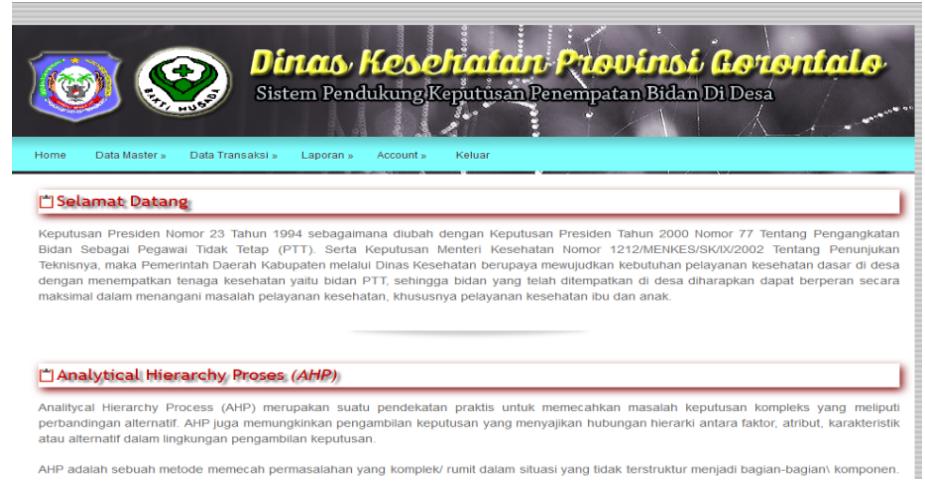

Gambar 3. Halaman Menu Utama Administrator

Menu utama pada halaman menu utaman administrator terdiri dari beberapa panel menu, antara lain Home, Visi Misi, Sejarah Kantor, Modul Pengguna yang berada pada panel menu atas. Pada panel menu sebelah kiri teriri dari Data Tahun Anggaran, Data Lembaga, Data Kriteria, Data Sub Kriteria, Data Permohonan, Data Seleksi/Penilaian, Daftar Lembaga, Daftar Permohonan dan Daftar Hasil Seleksi.

3.3.3 Halaman Matriks Perbandingan Kriteria

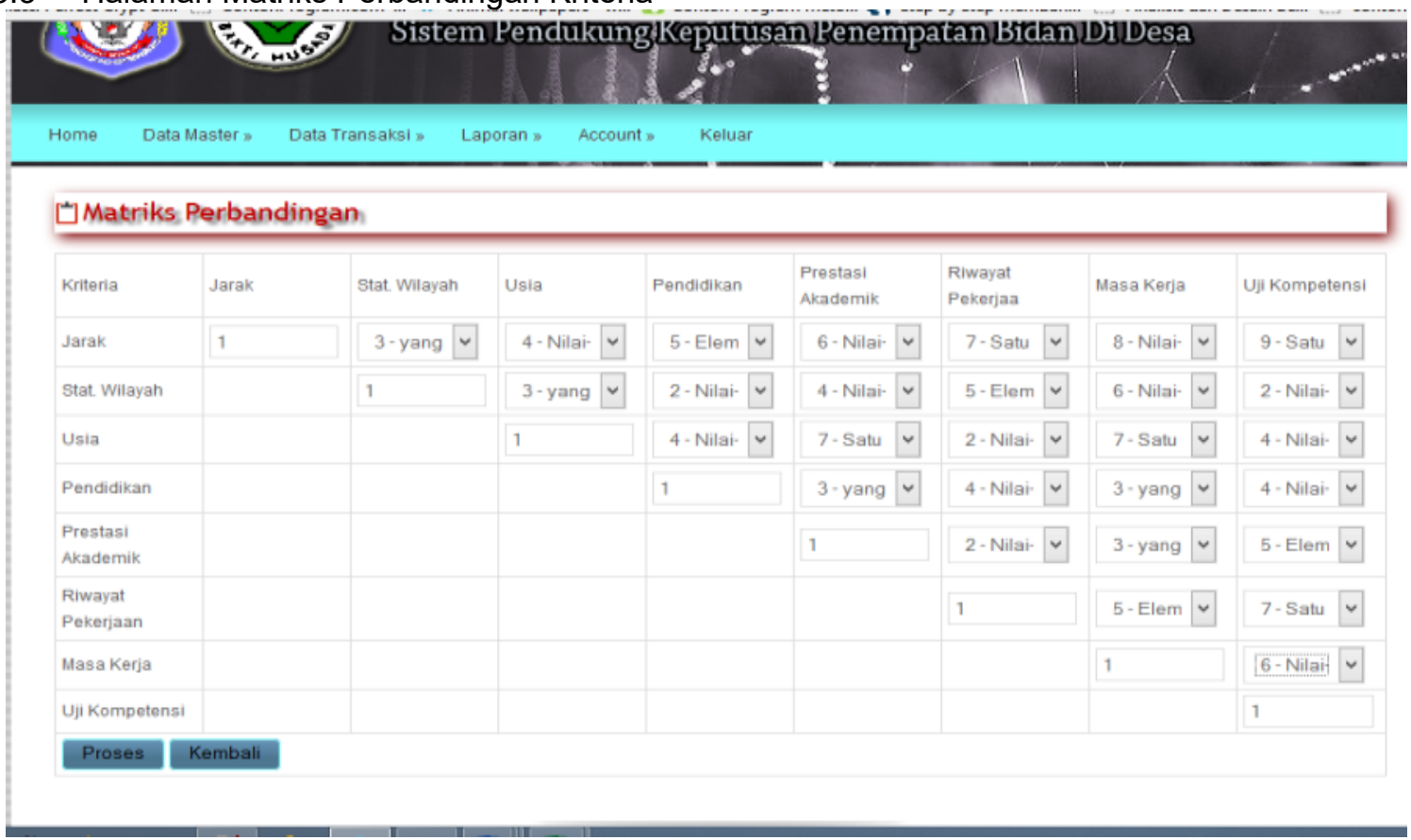

Gambar 4. Halaman Matriks Perbandingan kriteria

Form ini digunakan untuk memasukkan nilai pada masing - masing perbanding kriteria, kemudian klik tombol proses untuk melakukan perhitungan perbandingan matriks kriteria. Untuk membatalkan proses perhitungan nilai kriteria klik tombol kembali.

3.2.4 Data Penilaian

Data penilaian digunakan untuk menginputan data hasil penilaian bidan desa, dari hasil penilaian akan didapat hasil apakah seorang bidan layak menempati sebuah desa, untuk mengolah data penilaian bidan, yaitu :

1. Pilih sub menu penilaian pada menu data transaksi, sehingga tampil halaman seperti gambar di bawah. 


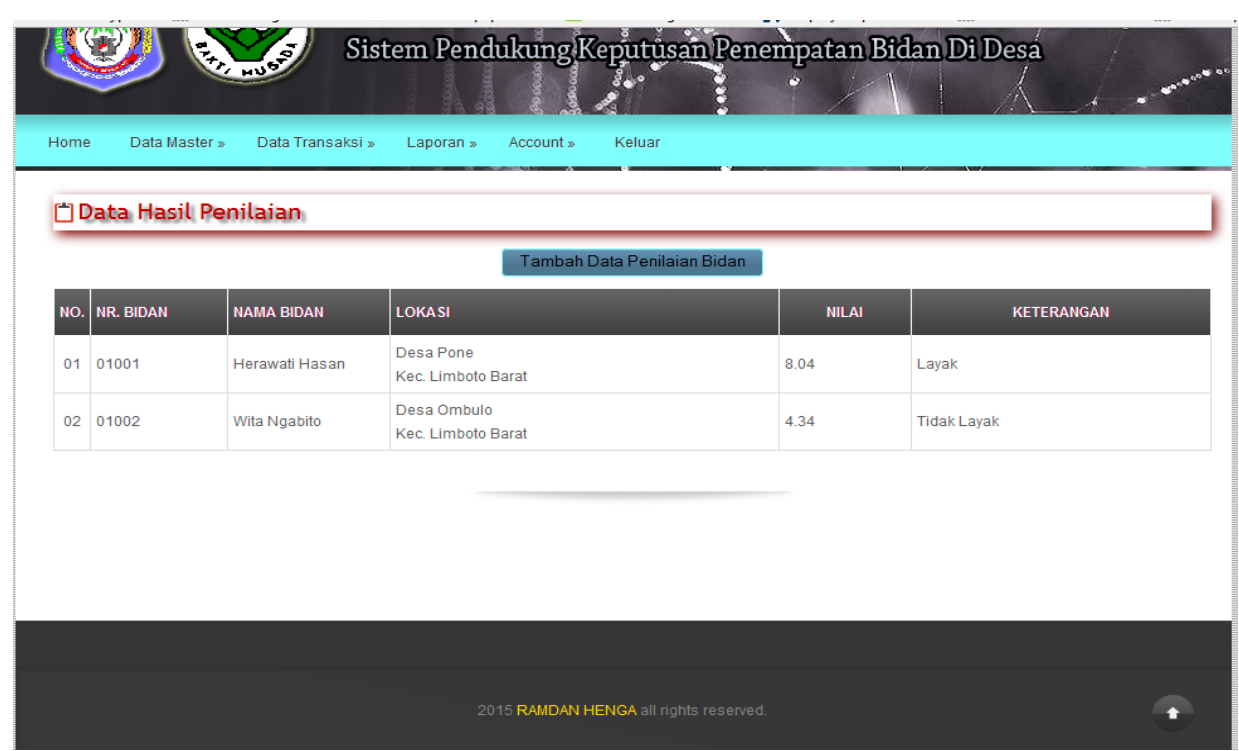

Gambar 5. Data Hasil Penilaian

2. Untuk menambah data klik tombol data penilaian

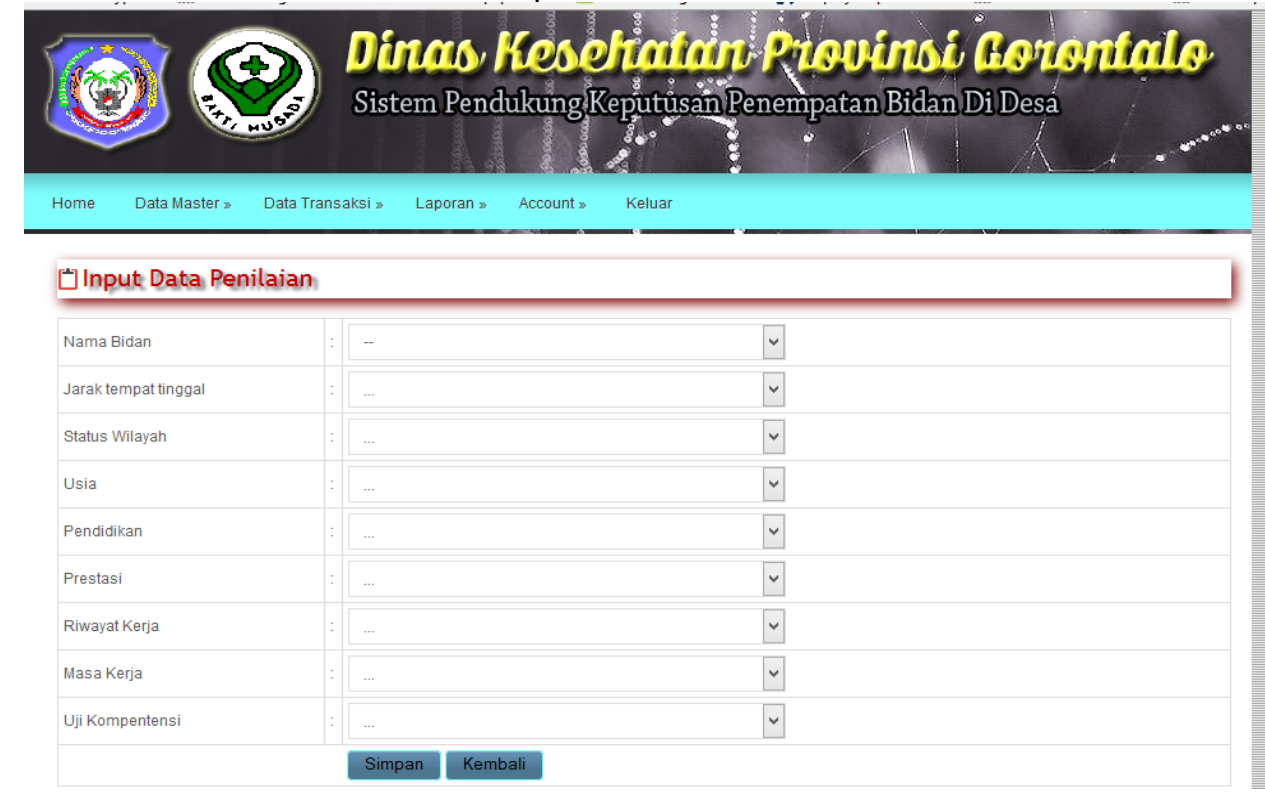

\section{Kesimpulan dan Saran}

Gambar 6. Halaman Input Data Penilaian

\subsection{Kesimpulan}

a. Dapat diketahui cara merekayasan Sistem Pendukung Keputusan Penempatan Bidan Di Desa dengan Menggunakan AHP pada Kantor Dinas Kesehatan Provinsi Gorontalo.

b. Sistem Pendukung Keputusan Penempatan Bidan di Desa dengan menggunakan AHP yang sudah direkayasa dapat diimplementasikan. Hal ini dibuktikan dengan hasil pengujian Sistem Pendukung Keputusan dan Hasil Pengujian Analytical Hierarchi Process (AHP), sehingga didapat bahwa pada rancangan perangkat lunak yang 4.3 Saran sudah dibuat telah terpenuhi dengan hasil sesuai dengan rancangan.

Berdasarkan pembahasan hasil penelitian dan kesimpulan di atas, saran-saran yang dapat diberikan penulis adalah sebagai berikut :

a. Sebaiknya peneliti selanjutnya dapat menggunakan metode FMADM yang lain untuk menyempurnakan hasil yang telah didapatkan. 
b. Apabila sistem ini akan diimplementasikan lansung ke pihak Dinas Kesehatan Provinsi Gorontalo, sebaiknya diadakan pelatihan penggunaan sistem tersebut.

\section{Daftar Pustaka}

[1] Kusrini. 2012. Studi Kinerja Bidan Di Desa Dalam Mengelola Program Desa Siaga Di Kabupaten Kebumen.

[2] Iqbal, Hartati. 2011. Aplikasi Sistem Pendukung Keputusan Penempatan Bidan PTT Pada Kabupaten Bireun.

[3] Sunarto. 2010. Sistem Pendukung Keputusan Pemilihan Handphone Menggunakan Metode AHP Berbasis PHP.

[4] Kusumadewi, Sri dkk. 2006. Fuzzy Multi Attribute Decison Making (FMADM). Yogyakarta.Graha IImu

[5] Hilya M. 2012. Sistem Pendukung Keputusan Menentukan Mahasiswa Lulusan Terbaik Di Perguruan Tinggi Menggunakan Metode AHP. 